\title{
The degradation and utilization of formaldehyde-treated urea by rumen microbes in vitro
}

\author{
jOUKO SETÄLÄ and LIISA SYRJÄLÄ-QVIST \\ Department of Animal Husbandry, University of Helsinki, 00710 Helsinki \\ 71, Finland
}

\begin{abstract}
Urea was treated with different levels of formaldehyde ( $\mathrm{HCHO})$. The $\mathrm{HCHO}$ percentages, on a weight basis, were $0\left(\mathrm{~F}_{0}\right), 0.25\left(\mathrm{~F}_{0.25}\right) 0.50\left(\mathrm{~F}_{0.50}\right), 0.75\left(\mathrm{~F}_{0.75}\right), 1.0\left(\mathrm{~F}_{1.0}\right), 1.5\left(\mathrm{~F}_{1.5}\right), 2.0\left(\mathrm{~F}_{2.0}\right), 3.0\left(\mathrm{~F}_{3.0}\right)$ and $5.0\left(\mathrm{~F}_{5.0}\right)$. Twenty milligrams of urea was incubated for 5 hours in $40 \mathrm{ml}$ of sheep rumen fluid-buffer solution (1:1) together with 1.5 grams of substrate. The substrate consisted of vacuum-dried and milled feeds: barley $(25 \%)$, molassed beet pulp $(25 \%)$ and $\mathrm{NaOH}$-treated straw $(50 \%)$. The feeds and urea were used in the same proportions as in the diet of the sheep which yielded the rumen fluid for incubation.

Treatment with $\mathrm{HCHO}$ decreased hydrolysis of urea to ammonia. The ammonia concentration in contents of fermentors 2 hours after the start of incubation had a highly significant $(P<0.001)$ negative correlation $(r=-0.976, n=72)$ with the $\mathrm{HCHO}$ treatment level. Microbial protein synthesis was calculated from tungstic acid - sulphuric acid precipitation. Synthesis of protein, expressed as grams of nitrogen per 100 grams fermented organic matter was highest when $F_{1.5}-F_{3.0}$ urea was used. Treatment with more than $3 \%$ of $\mathrm{HCHO}$ decreased the number of protozoa and the general activity of the microbes, thus decreasing fermentation of organic matter and lowering the yield of microbial protein. When $\mathrm{F}_{1.5}$ urea was used, the total yield ( $\mathrm{mg}$ protein/ $\mathrm{hr}$ ) was significantly higher than with untreated urea, but the results obtained with $F_{1.5}$ urea did not differ significantly from those with $F_{0.75}$ or $F_{2.0}$ urea.
\end{abstract}

\section{Introduction}

Since the studies of HART et al. (1939), urea has been used in the diets of ruminants. Problems have been caused by the very rapid degradation of urea to ammonia in the rumen. Hydrolysis is often too rapid compared with the capacity of the rumen microbes to utilize ammonia (BLOOMFIELD et al. 1960). This means that ammonia is absorbed through the rumen wall into the blood stream (LEWIS 1957), and levels higher than one percent of $\mathrm{NH}_{3}-\mathrm{N}$ in the blood cause a risk of ammonia toxification (CHALUPA 1968).

The energy source is a very important factor, when ammonia utilization is considered (MØLLER 1973, JOHNSON 1976). Besides using an appropriate energy source, it is necessary to maintain coupled fermentation, a balance between ammonia and energy release (McMENIMAN et al. 1976). This balance could be achieved by lowering the rate of urea hydrolysis. Both urease inhibitors (MAHADEVAN et al. 1976) and slow-release urea products such as 
urea-formaldehyde complexes (MILLIGAN et al. 1969, HUSTON et al. 1974, KULASEK et al. 1975) have been used. In practical feedings, however, it seems easier to use slow-release urea than inhibitors.

In this experiment the effect of formaldehyde treatments on urea utilization was studied. A formaldehyde-urea complex has already been used as a fertilizer, but a new processing technique made it seem desirable to test this complex and its possibilities in ruminant feeding as well.

\section{Materials and methods}

\section{Preparation of formaldehyde-urea}

Formaldehyde $(\mathrm{HCHO})$ was first mixed with urea and water. The liquid mixture contained $26.1 \%$ of urea, $59.9 \%$ of $\mathrm{HCHO}$ and $14.0 \%$ of water on a weight basis. Urea slurry was then reacted with this solution. The reaction time was about three minutes and the reaction temperature $+130^{\circ} \mathrm{C}$. After cooling the product was made into prills. The complex was prepared by Kemira Ltd.

\section{In vitro method}

The method was based on the technique used by TILLEY and TERRY (1963), but restricted to incubation in strained rumen fluid and buffer solution (McDOUGALL 1948).

Rumen fluid was collected from rumen-fistulated sheep. Their diet consisted of a mixture of barley and molassed beet pulp (1:1), and $\mathrm{NaOH}-$ treated wheat straw, both given at the rate of $0.5 \mathrm{~kg} / \mathrm{animal} / \mathrm{day}$.

Rumen contents were taken from different parts of the rumen in a warmed $\left(+39^{\circ} \mathrm{C}\right)$ insulated flask before the morning feeding. The contents were squeezed through four layers of cheese-cloth and the fluid was collected directly in a flask held in a water bath $\left(+39^{\circ} \mathrm{C}\right)$, and gassed with $\mathrm{CO}_{2}$. Warmed $\left(+39^{\circ} \mathrm{C}\right)$ buffer solution was then added to the flask and the mixture of rumen fluid and buffer solution (1:1) was gassed with $\mathrm{CO}_{2}$ until the $\mathrm{pH}$ of the mixture was 6.9.

The experimental substrate (not urea) was weighed into fermentors 16-20 hours before the start of incubation and kept in $+39^{\circ} \mathrm{C}$. The fermentors were glass tubes $(100 \mathrm{ml})$ fitted with rubber stoppers with gas release valves.

The incubation time was 5 hours and it started after the rumen fluidbuffer had been added the fermentors. After its addition the tubes were gassed with $\mathrm{CO}_{2}$ for about $5 \mathrm{sec}$. and transferred to an incubator $\left(+39^{\circ} \mathrm{C}\right)$. During incubation the $\mathrm{pH}$ of the fermentors was followed carefully and kept within the range 6.6-6.9 with warmed $2 \mathrm{~N} \mathrm{Na}_{2} \mathrm{CO}_{3}$.

The incubation substrate was 0.75 grams of $\mathrm{NaOH}$-treated wheat straw, 0.75 grams of the concentrate mixture given to the donor animals and 0.020 grams of urea. Before incubation the straw and the mixture were vacuum- 
dried $\left(+60^{\circ} \mathrm{C}\right)$ and milled with a $1-\mathrm{mm}$ screen. The urea was treated with the following percentages of $\mathrm{HCHO}$, on a weight basis: $0\left(\mathrm{~F}_{0}\right), 0.25\left(\mathrm{~F}_{0.25}\right), 0.50$ $\left(\mathrm{F}_{0.50}\right), 0.75\left(\mathrm{~F}_{0.75}\right), 1.0\left(\mathrm{~F}_{1.0}\right), 1.5\left(\mathrm{~F}_{1.5}\right), 2.0\left(\mathrm{~F}_{2.0}\right), 3.0\left(\mathrm{~F}_{3.0}\right)$ and $5.0\left(\mathrm{~F}_{5.0}\right)$.The substrate was incubated in $40 \mathrm{ml}$ of buffer-rumen fluid solution, and there were 10-12 incubations per treatment level, except for levels $F_{3.0}$ and $F_{5.0}$, for which only four incubations per treatment were performed.

The dry matter contents of components in the substrate were determined by oven heating at $100^{\circ} \mathrm{C}$ or in the analysis for urea, by Fisher titration. The nitrogen content of urea was calculated by the Kjeldahl method. The vacuum-dried samples of straw, barley and molassed beet pulp were analyzed by the methods of PALOHEIMO (1969). True protein content was determined according to BARNSTEIN (1935).

The release of ammonia from the urea was followed at intervals of an hour from the start of incubation. For this purpose, there were two fermentors per incubation hour. The fermentors were removed and their contents were centrifuged at $2000 \mathrm{rpm}$ for $10 \mathrm{~min}$.

The sediment was discarded, and the $\mathrm{pH}$ and ammonia content (McCULLOUGH 1967) of the supernatant were determined. The release of ammonia from urea was calculated according to principles of DINIUS et. al. (1974).

After 5 hours' incubation microbial protein was determined on the supernatant by sodium tungstate - sulphuric acid precipitation. Protein was determined as nitrogen by the Kjeldahl method, using $\mathrm{K}_{2} \mathrm{SO}_{4}$ and $\mathrm{HgO}$ as catalysts. The method of WINTER et al. (1964) modified by SETÄLÄ (1981 a) was used. When the synthesis of microbial protein was calculated, account was taken of the protein content of both the substrate and rumen fluid before incubation.

In the $F_{0}, F_{1.0}, F_{3.0}$ and $F_{5.0}$ treatments the concentration of VFA was determined on the supernatants obtained from the rumen fluid before incubation and from the fermentor contents after incubation. The determination was made by gas-liquid chromatography (HUIDA 1973).

\section{Statistical analyses}

The results were processed with a MONROE 1860 computor using its statistical programs. The differences between treatments means were tested by the Tukey test (STEEL and TORRIE 1960).

\section{Results}

Formaldehyde treatment decreased the dry matter content of urea (Table $1)$, but had no effect on its nitrogen content. The crude protein $(\mathrm{N} \times 6.25)$ content of the substrate dry matter was calculated as about $13.2 \%$ with urea and about $8.9 \%$ without.

The ammonia concentration in the fermentor contents was highest 2 hours after the start of incubation (Fig. 1). When less than $3 \% \mathrm{HCHO}$ was 
Table 1. Composition of feeds and urea used in incubations.

\begin{tabular}{|c|c|c|c|c|c|c|c|}
\hline & DM, \% & Ash & $\begin{array}{c}\text { Crude } \\
\text { protein }{ }^{1} \text { ) }\end{array}$ & $\begin{array}{c}\text { True } \\
\text { protein }\end{array}$ & $\begin{array}{l}\text { Ether } \\
\text { extract }\end{array}$ & $\begin{array}{l}\text { Crude } \\
\text { fiber }\end{array}$ & $\begin{array}{l}\mathrm{N} \text {-free } \\
\text { extracts }\end{array}$ \\
\hline & & \multicolumn{3}{|c|}{$\%$ in DM } & & & \\
\hline Barley & 87.6 & 2.7 & 13.5 & 12.4 & 2.1 & 5.3 & 76.3 \\
\hline Molassed beet pulp & 86.7 & 9.1 & 13.2 & 7.8 & 0.3 & 15.4 & 61.8 \\
\hline $\mathrm{NaOH}$-treated straw & 81.6 & 9.7 & 4.1 & 3.7 & 0.7 & 45.8 & 39.7 \\
\hline \multicolumn{8}{|l|}{ Urea } \\
\hline Untreated $\left(\mathrm{F}_{0}\right)$ & 99.8 & & 46.5 & & & & \\
\hline $0.25 \%$ of $\mathrm{HCHO}\left(\mathrm{F}_{0.25}\right)$ & 99.5 & & 46.6 & & & & \\
\hline $0.50 \%$ of $\mathrm{HCHO}\left(\mathrm{F}_{0.50}\right)$ & 99.7 & & 46.5 & & & & \\
\hline $0.75 \%$ of $\mathrm{HCHO}\left(\mathrm{F}_{0.75}\right)$ & 99.4 & & 46.7 & & & & \\
\hline $1.0 \%$ of $\mathrm{HCHO}\left(\mathrm{F}_{1.0}\right)$ & 99.4 & & 46.5 & & & & \\
\hline $1.5 \%$ of $\mathrm{HCHO}\left(\mathrm{F}_{1.5}\right)$ & 99.3 & & 46.5 & & & & \\
\hline $2.0 \%$ of $\mathrm{HCHO}\left(\mathrm{F}_{2.0}\right)$ & 99.1 & & 46.5 & & & & \\
\hline $3.0 \%$ of $\mathrm{HCHO}\left(\mathrm{F}_{3.0}\right)$ & 98.9 & & 46.5 & & & & \\
\hline $5.0 \%$ of $\mathrm{HCHO}\left(\mathrm{F}_{5.0}\right)$ & 98.2 & & 46.5 & & & & \\
\hline
\end{tabular}

1) Values for urea given as $\mathrm{N} \%$

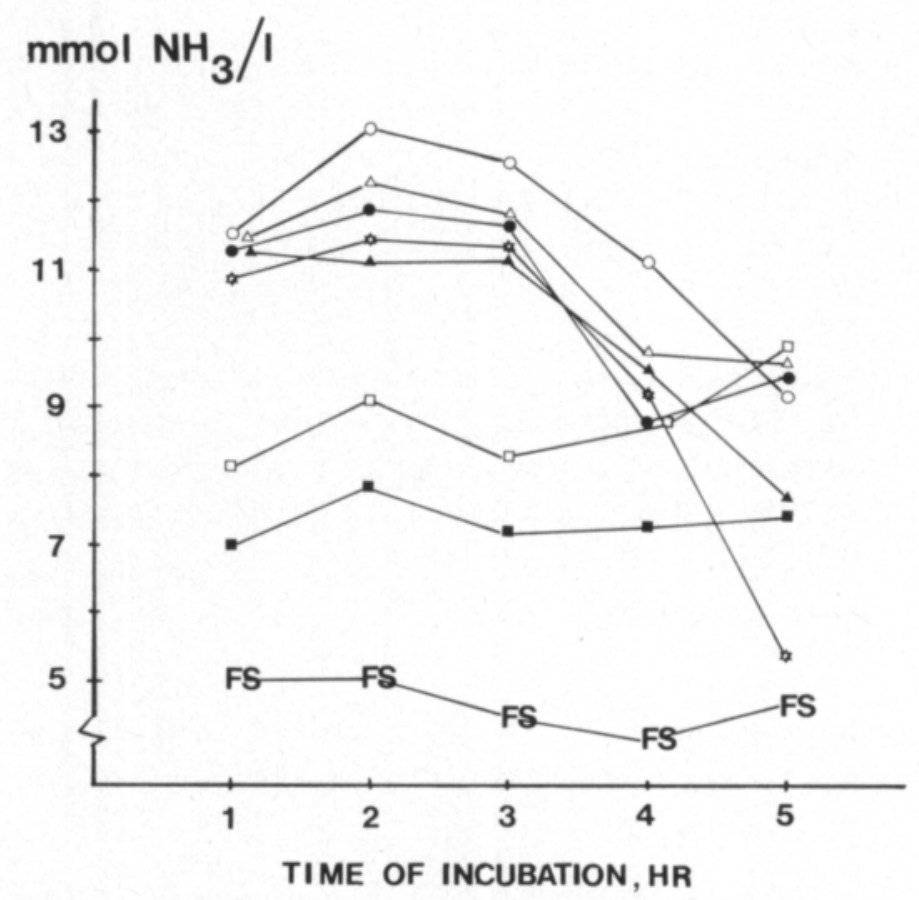

Figure 1. Changes in ammonia concentration in fermentor contents, when feed substrate was incubated

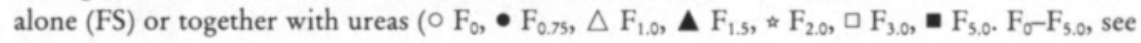
Table 1).

used, the concentration decreased towards the end of incubation.

The ammonia levels in the contents of fermentors after 2 hours' incubation showed a significant negative correlation $\left(\mathrm{r}=-0.976^{\% * \%}\right)$ with the $\mathrm{HCHO}$ treatment levels (Fig. 2). The proportion of untreated urea hydrol- 


\section{$\log \mathrm{NH}_{3}, \mathrm{mmol} / \mathrm{I}$}

Figure 2. Effect of $\mathrm{HCHO}$ treatment on peak values of ammonia concentration in fermentor contents after 2 -hr incubation $(\mathrm{n}=$ 72).

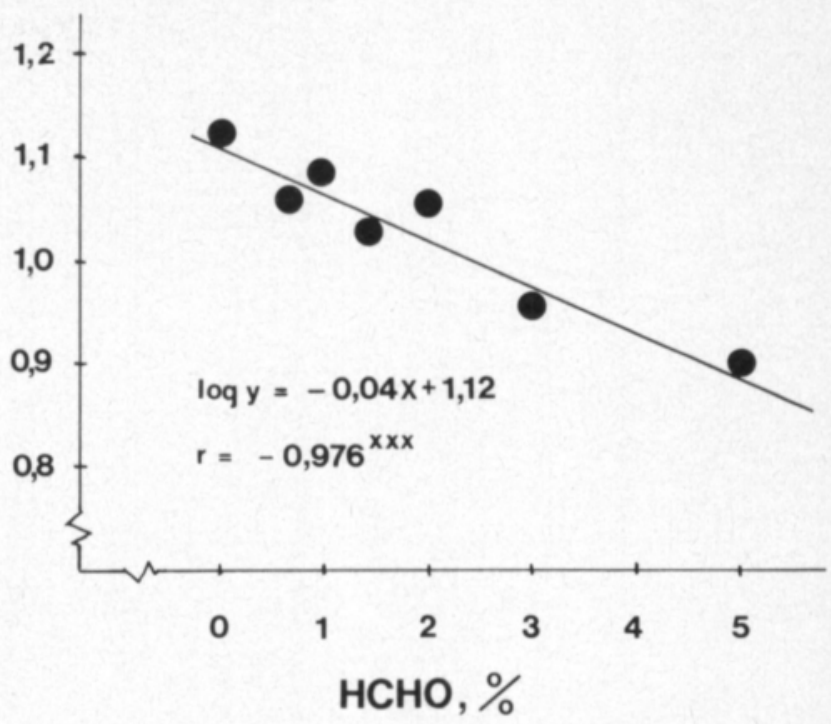

ysed to ammonia during the first 2 hours was calculated as $97 \%$. In the $\mathrm{HCHO}$ treatments, the $\mathrm{F}_{1.0}$ urea $(1 \% \mathrm{HCHO})$ was the most strongly degraded. In preliminary tests the hydrolysis of $\mathrm{F}_{0.25}-\mathrm{F}_{0.50}$ urea varied widely and these treatments were excluded from further experiments.

When the $\mathrm{HCHO}$ treatment level was plotted directly against the ammonia concentration in the contents of fermentors, four different levels of urea degradation were found. With treatments of $\mathrm{F}_{0.25-1.0}, \mathrm{~F}_{1.5-2.0}, \mathrm{~F}_{3.0}$ and $\mathrm{F}_{5.0}$, the percentages of urea hydrolysed to ammonia were after 2 hours' incubation, respectively: $91-94,82-84,62$ and 44.

Microbial protein synthesis calculated as $\mathrm{mg} / \mathrm{hr}$ was significantly higher $\left(P<0.01\right.$ ) with $F_{0.75}, F_{1.5}$ and $F_{2.0}$ urea than with the substrate (Fig. 3, Table 2). Addition of $F_{0}, F_{1.0}$ and $F_{3.0}$ urea to the substrate did not increase protein synthesis significantly. There were no significant differences between the $\mathrm{HCHO}$ treatments within these two groups (Table 2), but the difference between these groups was significant $(P<0.01)$. Treatment with $5 \%$ $\mathrm{HCHO}$ had a clearly inhibitory effect on protein synthesis under these in vitro conditions. The results of the $\mathrm{F}_{5.0}$ incubations were significantly lower $(P<0.01)$ than the values obtained with the feed substrate alone and with substrate complemented with untreated urea.

When the microbial protein synthesis was calculated as $\mathrm{g} \mathrm{N} / 100 \mathrm{~g}$ fermented organic matter (OMF), the optimum treatment level was $F_{1.5}-3.0$ (Table 2). $\mathrm{HCHO}$ affected the fermentation and hence the final VFA concentration in the fermentor contents. However, VFA differed significantly $(\mathrm{P}<0.05)$ only between the treatment levels $\mathrm{F}_{0-1.0}$ and $\mathrm{F}_{5.0}$. Within the limited $\mathrm{pH}$ range used here $\mathrm{HCHO}$ caused only minor changes in the nature of fermentation during the incubation period. 


\section{yield of microbial protein, $\mathrm{mg} / \mathrm{hr} / 100 \mathrm{ml}$}

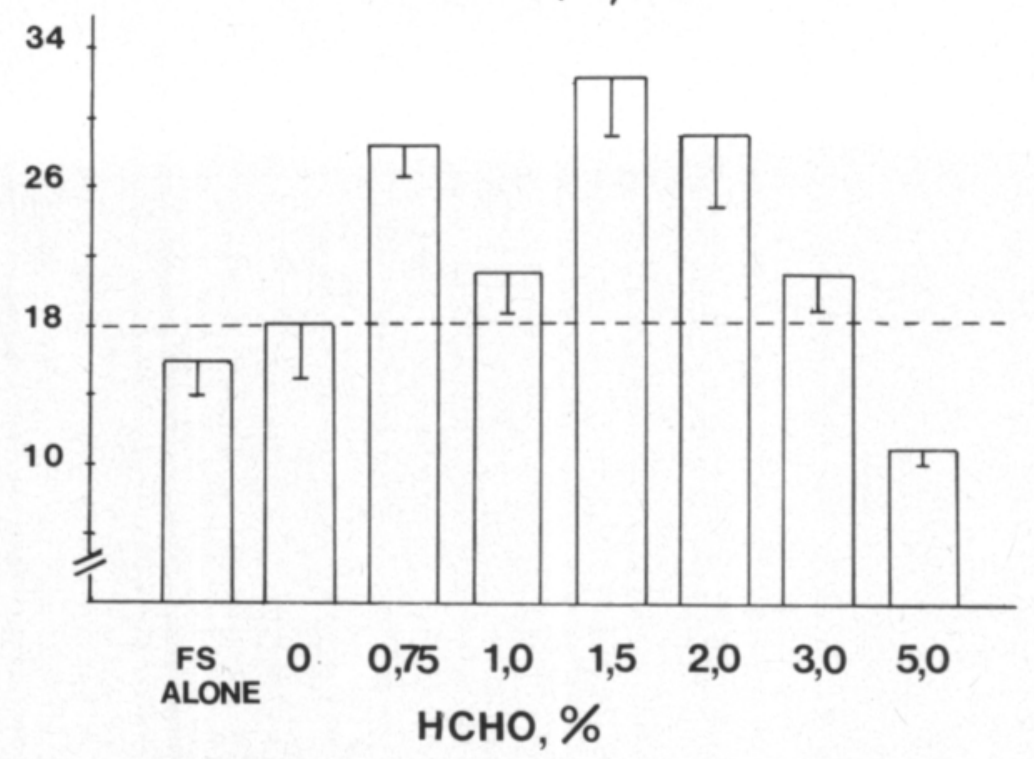

Figure 3. Effect of $\mathrm{HCHO}$ treatment on microbial protein synthesis, when feed substrate (FS) was incubated alone or together with untreated and $\mathrm{HCHO}-$ treated ureas.

Table 2. Volatile fatty acids (VFA), fermentation of organic matter (OM) and microbial protein synthesis in incubations containing urea treated with different levels of $\mathrm{HCHO}\left(\mathrm{F}_{\sigma}-\mathrm{F}_{5,0}\right.$, see Table 1).

\begin{tabular}{|c|c|c|c|c|c|c|c|}
\hline & \multicolumn{7}{|c|}{ Incubation } \\
\hline & \multicolumn{7}{|c|}{ FEED SUBSTRATE + UREA } \\
\hline & $F_{0}$ & $F_{0.75}$ & $F_{1.0}$ & $F_{1.5}$ & $\mathrm{~F}_{2.0}$ & $F_{3.0}$ & $F_{5.0}$ \\
\hline Total VFA after incubation, $\mathrm{mmol} / \mathrm{l}^{1}$ ) & $209^{2}$ & - & $220^{2}$ & - & - & $184^{\text {ab }}$ & $178^{\mathrm{b}}$ \\
\hline \multicolumn{8}{|l|}{ Mole- $\%$ of VFA } \\
\hline Acetic & 70 & - & 71 & - & - & 67 & 72 \\
\hline Propionic & 20 & - & 17 & - & - & 19 & 19 \\
\hline Isobutyric, Butyric & 9.7 & - & 13.0 & - & - & 12.0 & 7.6 \\
\hline Isovaleric, Valeric & 0.3 & - & + & - & - & 2.0 & 1.4 \\
\hline OM fermented (OMF), $\%^{2}$ ) & $83.5^{\mathrm{a}}$ & - & $87.8^{a}$ & - & - & $73.7^{\mathrm{ab}}$ & $71.1^{\mathrm{b}}$ \\
\hline \multicolumn{8}{|l|}{ Microbial protein synthesis } \\
\hline $\mathrm{g} \mathrm{N} / 100 \mathrm{~g} \mathrm{OMF}^{3}$ ) & 1.45 & 1.81 & 1.90 & 2.18 & 2.11 & 2.08 & 1.30 \\
\hline $\mathrm{mg}$ protein $/ \mathrm{hr} / 40 \mathrm{ml}$ & $7.2^{c}$ & $11.5^{\mathrm{d}}$ & $8.4^{c}$ & $12.9^{\mathrm{d}}$ & $11.7^{\mathrm{d}}$ & $8.5^{c}$ & $4.4^{e}$ \\
\hline \multicolumn{8}{|l|}{$\mathrm{g} \mathrm{HCHO} / 100 \mathrm{~g}$} \\
\hline crude protein in whole substrate & - & 0.11 & 0.15 & 0.23 & 0.30 & 0.45 & 0.75 \\
\hline
\end{tabular}

Differences between means with different letters are statistically significant: $a-b(P<0.05), c-e(P<0.01)$

1) Adjusted for the same initial concentration before incubation.

${ }^{2}$ ) Calculated on basis of VFA yield (CZERKAWSKI 1978).

3) Calculated with the formula $y=1.45+0.57 X-0.12 X^{2}$ (SETÄLÄ 1981a), in which X = HCHO treatment, \%.

\section{Discussion}

The mechanism of the influence of the $\mathrm{HCHO}$ treatment on the rate of urea hydrolysis is very likely the chemical bonds between urea and formal- 
dehyde. At least this is the case when protein is treated with formaldehyde (VAN DOOREN 1972) and it has not been shown that formaldehyde can for instance, inhibit the action of urease. In the experiments of MILLIGAN et al. (1969) and HUSTON et al. (1974) HCHO-treated urea was degraded more slowly to ammonia than untreated urea.

When the degradation values for the different $\mathrm{HCHO}$ treatments are considered, two points should be noted.

Firstly, the values were calculated after 2 hours' incubation, when the ammonia concentration was at its peak. After this ammonia decreased, due to its utilization in protein synthesis, and it would have been misleading to calculate the degradation at the end of incubation. However, it is possible that considerable degradation of $F_{3.0}$ and $F_{5.0}$ urea occurred during the incubation period from 3 to 5 hours.

Secondly we assumed in our calculations that the "endogenous ammonia" originating from the rumen fluid, was not changed during incubation. This assumption was probably true, because due to lysis of rumen microbes, changes in the "endogenous ammonia concentration" have been observed only when no substrate was included in the incubation (GÖRSCH and BERGNER 1978, SETÄLÄ 1981b).

The ammonia level in the fermentor contents cannot have been a factor limiting microbial protein synthesis. The levels were higher than the suggested requirements for maximal protein synthesis (SATTER and SLYTER 1974, NIKOLIC et al. 1975, SLYTER et al. 1979). It, therefore appears that the energy available for microbes (JOHNSON1976, McMENIMAN et al. 1976) was the most important factor in the present conditions.

The rate of energy release achieved when urea was treated with 1.5-3.0\% $\mathrm{HCHO}$ evidently gave the optimum ammonia/energy ratio for protein synthesis.

After treatment levels lower than $1.5 \% \mathrm{HCHO}$, the ammonia/energy ratio was too high. At higher treatment levels there was less ammonia, but, judging from the lower fermentation of organic matter (SETÄLÄ 1981a), also less available energy and the yield of microbial protein was poor. The relatively high yield of protein obtained with $\mathrm{F}_{3.0}$ urea was also probably partly due to a higher proportion of bacteria in the microbiota of the fermentor contents (MERCER et al. 1980).

Changes in the yield of total VFA and in the fermentation pattern at the treatment level of $5 \% \mathrm{HCHO}$ may partly be explained by the death of protozoa. In qualitative studies with a microscope it was noted that there were fewer protozoa in the $\mathrm{F}_{3.0}$ incubations and that they were totally absent after incubation with $F_{5.0}$ urea (see also BIRD and LENG 1978). HEMPELZAWITKOWSKA and KULASEK (1974) suggested that formaldehyde could affect the protozoa population at as low a level as $3 \% \mathrm{HCHO}$. THORNTON et al. (1977) suggested that although formaldehyde might not affect the number of microbes, it could decrease their activity at levels of $0.2-0.5 \%$ in the diet.

The low protein synthesis with $\mathrm{F}_{1.0}$ urea was rather unexpected, because the amount of fermented organic matter was highest when this urea was used. 
Since the ammonia release from $F_{1.0}$ urea was also high, it is possible that the reaction between urea and $\mathrm{HCHO}$ was not properly balanced. This may also apply to the $\mathrm{F}_{0.25}$ and $\mathrm{F}_{5.0}$ urea. According to KRALOVEC and MORGAN (1954), the ratio of urea to $\mathrm{HCHO}$ has an important influence on the character of the complex.

The values obtained for microbial protein synthesis agreed with those cited in the review by STERN and HOOVER (1979). It should be pointed out that our values represent mainly bacterial protein, because the protozoa were separated with feed particles by centrifugation (WARNER 1966). Nor can the possibility be excluded that feed particles and soluble feed protein were left in the supernatant from which the microbial protein was extracted by precipitation. The separation of microbial protein from feed protein is difficult and the other methods also have their shortcomings (see SETÄLÄ 1981 a). According to microscopic studies, contamination by feed particles in the supernatant must have been small. HILLER and Van SLYKE (1922) showed that tungstate precipitated peptides besides protein. CZERKAWSKI (1978) therefore suggested that when protein is determined as the nitrogen precipitated, the results should be multiplied by 0.7 to obtain microbial protein synthesis on normal diets. This correction was made in the calculation of our results.

Acknowledgements. The authors wish to express their acknowledgements to Kemira Ltd. for preparing the treated ureas and to Mr. Risto Kauppinen and Miss Marja Palm for the technical assistance during the experiment.

\section{References}

BARNSTEIN, F. 1935. Bestimmung der Reinproteins. Handbuch der Lebensmittelchemie II. p. 607 Berlin.

BIRD, S. H. \& LENG, R. A. 1978. The effects of defaunation of the rumen on the growth of cattle on low-protein high-energy diets. Br. J. Nutr. 40: 163-167.

BLOOMFIELD, R. A., GARNER, G. B. \& MOHRER, M. E. 1960. Kinetics of urea metabolism in sheep. J. Anim. Sci. 19: 1248.

CHALUPA, W. 1968. Problems in feeding urea to ruminant. J. Anim. Sci. 27: 207-219.

CZERKAWSKI J. W. 1978. Reassesment of efficiency of synthesis of microbial matter in the rumen. J. Dairy Sci. 61: 1261-1273.

DINIUS, D. A., LYON, C. K. \& WALKER, H. G., Jr. 1974. In vitro evaluations of protein and proteinsafflower oil complexes treated with formaldehyde. J. Anim. Sci. 38: 467-474.

GÖRSCH, R. \& BERGNER, H. 1978. Prüfung einiger Harnstoffderivate unter in vitro-Bedingungen. Arch. Tierern. 30: 221-228.

HART, E. B., BOHSTEDT, G., DEOBALD, H. J. \& WEGNER, M. I. 1939. The utilization of sample nitrogenous compounds such as urea and ammonium bicarbonate by growing calves. J. Dairy Sci. 22: 785-798.

HEMPEL-ZAWITKOWSKA, J. \& KULASEK, G. 1974. Influence of nitrogen components in the sheep's diet on the protozoa counts and protozoa genera in the rumen. Prace i Materialy Zootechniczne 6: 13-22.

HILLER, A. \& SLYKE, Van D. D. 1922. A study of certain protein precipitants. J. Biol. Chem. 53: 253-267.

HUIDA, L. 1973. Quantitative determination of volatile fatty acids from rumen sample and silage by gasliquid chromatography. J. Scient. Agric. Soc. Finl. 45: 483-488. 
HUSTON, J. E., SHELTON, B. \& BREUER; L. H. 1974. Effect of rate of release of urea on its utilization by sheep. J. Anim. Sci. 39: 618-628.

JOHNSON, R. R. 1976. Influence of carbohydrate solubility on nonprotein nitrogen utilization in the ruminant. J. Anim. Sci. 43: 184-191.

KRALOVEC, R. D. \& MORGAN, W. A. 1954. Condensation products of urea and formaldehyde as fertilizer with controlled nitrogen availability. J. Agric. Food Chem. 2: 92-95.

KULASEK, G., LEONTONOWICZ, H. \& KRASICKA, B. 1975. Urea-furfural polymer (UFP) as a protein replacer for sheep. Roczniki Nauk Rolniczych, ser. B. 96: 67-76.

LEWIS, D. 1957. Blood-urea concentration on relation to protein utilization in the ruminant. J. agric. Sci., Camb. 48: 438-446.

MAHADEVAN, S., SAUER, F. \& ERFLE, J. D. 1976. Studies on bovine rumen bacterial urease. J. Anim. Sci. 42: 745-753.

McCULLOUGH, H. 1967. The determination of ammonia in whole blood by a direct colorimetric method. Clin. Chem. Acta 17: 297-304.

McDOUGALL, E. I. 1948. Studies on ruminant saliva 1. The composition and output of sheep's saliva. Anal. Biochem. 43: 99-109.

Mc MENIMAN, N. P., BEN-GHEDALIA, D. \& ARMSTRONG, D. G. 1976. Nitrogen-energy interactions in rumen fermentation. Protein metabolism and nutrition. EAAP publ. 16: 217-227.

MEGGISON, P. A., McMENIMAN, N. P. \& ARMSTRONG, D. G. 1979. Efficiency of microbial protein synthesis in cattle. Proc. Nutr. Soc. 38: 146A.

MERCER, J. R., ALLEN SARAH, A. \& MILLER E. L. 1980. Rumen bacterial protein synthesis and the proportion of dietary protein escaping degradation in the rumen of sheep. Br. J. Nutr. 43: 421-433.

MILLIGAN, L. P., ROBBLEE,A. R., WOOD, J. C., KAY, W. C. \& CHAKRABARTTY, S. K. 1969. A new non-protein nitrogen source for ruminants. Can. J. Anim. Sci. 49: 135-141.

MØLLER, P. D. 1973. The influence of different carbohydrate sources on the utilization of urea nitrogen by lactating cows. 412 . Beretn. Landøkon. Forsogslab. 204 p.

NIKOLIC, J. A., JOVANOVIC, M. \& FILIPOVIC, R. 1975. Microbial protein synthesis by bovine rumen content in relation to ammonia concentration. Tracer studies on non-protein nitrogen for ruminants II. p. 43-54. IAEA, Vienna.

PALOHEIMO, L. 1969. Weender Analyse. Handb. der Tierern. I. p. 164-171. Hamburg.

SATTER, L. D. \& SLYTER, L. L. 1974. Effect of ammonia concentration on rumen microbial protein production in vitro. Br. J. Nutr. 32: 199-208.

SETÄLÄ, J. 1981 a. Formaldehydi-urean hyväksikäyttö märehtijällä. Lic. thesis, Univ. Helsinki, Dept. of Anim. Husb. 95 p.

- 1981 b. Unpublished observation.

SLYTER, L. L., SATTER, L. D. \& DINIUS, D. A. 1979. Effect of ruminal ammonia concentration on nitrogen utilization by steers. J. Anim. Sci. 48: 906-912.

STEEL, R. G. \& TORRIE, J. H. 1960. Principles and procedures of statistics. New York. 481 p.

STERN, M. D. \& HOOVER, W. H. 1979. Methods for determining and factors affecting rumen microbial protein synthesis: a review. J. Anim. Sci. 49: 1590-1603.

THORNTON, J. H., OWENS, F. N., WILliaMS, D. E. \& PRIGGE, E. C. 1977. Fermentation and digestion of formaldehyde treated ensiled high moisture corn grain. Anim. Sci. Res. Rep., Oklahoma Agric. Exp. Stat. 101: 62-67.

TILLEY, J. M. A. \& TERRY, R. A. 1963. A two-stage technique for in vitro digestion of forage crops. J. Br. Grassl. Soc. 18: 104-111.

VAN DOOREN, P. 1972. The mode of action of formaldehyde on proteins. Repr. $129 \mathrm{p}$.

WARNER, A. C. I. 1966. Diurnal changes in the concentrations of micro-organisms in the rumens of sheep fed limited diets once daily. J. Gen. Microbiol. 45: 213-235.

WINTER, K. A., JOHNSON, R. R. \& DEHORITY, B. A. 1974. Metabolism of urea nitrogen by mixed cultures of rumen bacteria grown on cellulose. J. Dairy Sci. 47: 793-797.

Ms received March 3, 1982. 


\title{
Formaldehydillä käsitellyn urean hajoaminen ja hyväksikäyttö in vitro -olosuhteissa
}

\author{
Jouko Setälä ja Liisa Syrjälä-Qvist \\ Helsingin yliopiston kotieläintieteen laitos. 00710 Helsinki 71
}

Tutkimuksessa selvitettiin formaldehydi $(\mathrm{HCHO})$-käsittelyjen vaikutusta urean hajoamiseen ja ureatypen hyväksikäyttöön. Formaldehydi-tasot olivat $0 \%\left(\mathrm{~F}_{0}\right), 0.25 \%\left(\mathrm{~F}_{0.25}\right), 0.5 \%\left(\mathrm{~F}_{0.5}\right), 0.75 \%$ $\left(\mathrm{F}_{0.75}\right), 1.0 \%\left(\mathrm{~F}_{1.0}\right), 1.5 \%\left(\mathrm{~F}_{1.5}\right), 2.0 \%\left(\mathrm{~F}_{2.0}\right), 3.0 \%\left(\mathrm{~F}_{3.0}\right)$ and $5.0 \%\left(\mathrm{~F}_{5.0}\right)$ formaldehydiä painoprosentteina. Urea $(20 \mathrm{mg})$ inkuboitiin yhdessä rehusubstraatin $(1.5 \mathrm{~g})$ kanssa. Rehusubstraatti muodostui vakuumi-kuivatusta ja analyysimyllyllä jauhetusta ohrasta $(25 \%)$, melassileikkeestä $(25 \%)$ ja kuivalipeöidystä oljesta (50\%). Inkubointi suoritettiin pötsineste-puskuriliuos (1:1) -seoksessa (40 ml) ja inkubaatioajan pituus oli viisi tuntia. Käytetyt rehut ja niiden keskinäiset suhteet vastasivat tarkasti ruokintaa, jota käytettiin lampaille, joilta pötsineste otettiin inkubaatiota varten.

Formaldehydi-käsittely vähensi urean hajoamista ammoniakiksi. Fermentorin sisällöstä kahden tunnin kuluttua inkubaation alusta mitatun ammoniakin määrän ja $\mathrm{HCHO}$-käsittelytason välillä oli merkitsevä $(P<0.001)$, negatiivinen $(r=-0.976, n=72)$ korrelaatio.

Mikrobiproteiinisynteesi analysoitiin wolframaatti-rikkihappo-saostuksen avulla. Fermentoitunutta orgaanista ainetta kohti laskettuna synteesi oli suurin, kun käytettiin $F_{1.5^{-}}, F_{2.0^{-}}$ja $F_{3.0^{-}}$ureaa. Kolmen prosentin formaldehydi-käsittelystä lähtien formaldehydi alensi alkueläinten lukumäärää, käymisen voimakkuutta ja orgaanisen aineen sulavuutta inkubaation aikana. Kokonaisproteiinisynteesi (mg proteiinia/ hr) oli merkitsevästi $(\mathrm{P}<0.01)$ suurempi käsittelemättömällä urealla saatuun synteesiin verrattuna, kun käytettiin $F_{1.5}$-ureaa. Tällä urealla saadut tulokset eivät poikenneet merkitsevästi $F_{0.75}$ - ja $F_{2.0}$-urealla saaduista proteiinisynteesin arvoista. 